Масицька, Тетяна. «Різновиди семантико-синтаксичної залежності суб’єкта дії у прозових творах Йосипа Струцюка». Лінгвостилістичні студії, вип. 11, 2019, с. 100-10.

Masytska, Tetiana. "Semantic-syntactic Dependency Varieties of the Subject of Action in Joseph Strutsiuk's Prose". Linguostylistic Studies, iss. 11, 2019, pp. 100-10.

УДК 811.161.2'367.5:821.161.2(477.82)'06-3.09Струцюк

https://doi.org/10.29038/2413-0923-2019-11-100-110

\title{
РІЗНОВИДИ СЕМАНТИКО-СИНТАКСИЧНОЇ ЗАЛЕЖНОСТІ СУБ'ЄКТА ДІЇ У ПРОЗОВИХ ТВОРАХ ЙОСИПА СТРУЦЮКА
}

\author{
Тетяна Масицька \\ Східноєвропейський національний університет імені Лесі Українки, \\ Луцьк, Україна
}

У статті проаналізовано різновиди семантико-синтаксичної залежності суб'єкта дії в прозових творах Йосипа Струцюка. Розмежовано поняття залежність і валентність. Встановлено, що у семантико-синтаксичній організації реченнєвої конструкції предикати зумовлюють суб'єктну залежність трьох основних різновидів. Виокремлено основні лексичні групи предикатів дії. Схарактеризовано семантичне вираження залежного суб'єкта дії та визначено його лексичні групи.

Ключові слова: структура речення, семантико-синтаксична залежність, предикат дії, суб'єкт дії.

\section{SEMANTIC-SYNTACTIC DEPENDENCY VARIETIES OF THE SUBJECT OF ACTION IN JOSEPH STRUTSIUK'S PROSE Tetiana Masytska}

Lesya Ukrainka Eastern European National University, Lutsk, Ukraine

The article highlights the varieties of semantic-syntactic dependency of the subject of action in Joseph Strutsuk's prose. The study deals with the components of the sentence and analyzes their functional features in terms of the syntactic dependencies concept. The semantic-syntactic aspect of a sentence structure allows tracing the peculiar features of a sentence component semantic expression and revealing the correlation between the form and content in it. The concepts of 'dependency' and 'valency' are distinguished. The valency is analyzed at the morphological level in accordance with different parts of speech. In terms of the semantic-syntactic structure of the sentence, the dependency is clearly focused on the study of sentence components, controled by the predicate. The number of components in the semantic-syntactic structure of a sentence depends on its semantic features. When studying the semantic-syntactic structure of a sentence, in the focus of attention is the concept of subject dependency. In the semantic-syntactic structure of the sentence predicates determine the subject dependence of three main varieties: 1) dependence of the action subject; 2) dependence of the process subject: 3) dependence of the state subject. The study has defined main lexical groups of predicates of action. The semantics of the subject of the action depends on the semantics of the predicate. In Joseph Strutsiuk's prose the dependency of subject is represented by 24 semantic groups. The semantic potential of the predicates of action determines the number of subject components and influences their significant

(C) Масицька Т., Східноєвропейський національний університет імені Лесі Українки, 2019.

Це стаття відкритого доступу на умовах CC BY-NC 4.0 
differentiation. The dependency analysis reflects the main tendencies of the semanticsyntactic structure of the sentence. The dependency syntax is challenging and promising topic for further researches.

Key words: structure of sentence, semantic-syntactic dependency, predicate of action, subject of action.

Вступ. Дослідники вітчизняного мовознавства вивчають компонентний склад семантико-синтаксичної структури речення, його семантику, взаємозв'язок власне-синтаксичної і семантичної структур із другої половини XX століття. У сучасному синтаксисі в останні десятиріччя по-новому розглядають речення як багаторівневу структуровану одиницю, його формально-синтаксичну, семантико-синтаксичну та комунікативну організацію. Теорія залежностей висвітлює процеси взаємодії семантичних компонентів у реченні й уможливлює розв'язок актуальних питань щодо проблем синтаксичної семантики, компонентного складу семантико-синтаксичної структури речення.

Суб'єктна синтаксема - найпоширеніший компонент семантикосинтаксичної структури речення - залежна від предиката. Дослідження різновидів суб'єктної залежності сприятиме чіткішому баченню основних тенденцій організації семантико-синтаксичної реченнєвої структури.

В українських лінгвістичних студіях проблематику суб'єкта розглядали І. Вихованець, М. Плющ, К. Городенська, А. Загнітко, О. Межов та інші мовознавці. На сучасному етапі дослідження різновидів суб'єкта залишається актуальним, оскільки висвітлює особливості структури авторського тексту. Проблематика, що охоплює вивчення різновидів залежних суб'єктних синтаксем, передбачає врахування денотативного, логіко-семантичного і мовно-семантичного рівнів семантики речення. $\mathrm{y}$ нашій розвідці спираємося на мовно-семантичний рівень, який орієнтований на семантико-синтаксичну структуру речення, на розгляд семантичних різновидів мінімальних синтаксичних одиниць у реченнєвій структурі.

Мета дослідження - визначити основні семантичні різновиди семантико-синтаксичної залежності суб'єкта дії у прозових творах Йосипа Струцюка. Для досягнення поставленої мети необхідно вирішити такі завдання: 1) схарактеризувати компонентний склад семантикосинтаксичної структури речення; 2) визначити семантичні типи найпоширеніших предикатів, що зумовлюють семантико-синтаксичну залежність суб'єкта дії; 3) укласти семантичні групи, що репрезентують варіанти семантико-синтаксичної залежності суб'єкта дії; 4) схарактеризувати семантичне ускладнення субстанційної семантикосинтаксичної залежності. Проведений аналіз семантико-синтаксичної залежностей суб'єкта дії сприятиме поглибленому вивченню семантикосинтаксичної структури речення, тому що суб’єкт і предикат є її основою. 
Матеріал i методи дослідження. Матеріалом дослідження послугували прозові твори Йосипа Струцюка, із яких відібрані реченнєві конструкції з семантико-синтаксичною залежністю суб'єкта дії. Як основні методи дослідження використано описовий метод із властивими йому прийомами зовнішньої і внутрішньої інтерпретацій - для детального, побудованого на комунікативно-прагматичних параметрах аналізу фактичного матеріалу та лінгвістичної систематизації мовних одиниць; системно-класифікаційний метод, що дав змогу проаналізувати реченнєві конструкції та виокремити різновиди суб'єктної залежності. Метод функційного аналізу слугував для з'ясування семантико-синтаксичної функції залежності суб’єкта дії; прийом компонентного аналізу - для диференціації семантичних різновидів семантико-синтаксичної залежності суб'єкта дії; прийом компаративного аналізу - для виявлення в реченнєвих конструкціях диференційних семантико-синтаксичних ознак семантико-синтаксичних залежностей репрезентованих суб'єктом дії.

Результати дослідження і дискусія. В українському синтаксисі кінця XX початку XXI століть до проблемних питань, що стосуються семантико-синтаксичної структури речення, належать компонентний склад реченнєвих конструкцій, аналіз семантико-синтаксичних відношень та ін. К. Шульжук, обгрунтовуючи ідеї, закладені у працях Л. Теньєра, Ч. Філлмора, У.-Л. Чейфа, Й. Андерша, І. Вихованця, зауважив, що «сучасне українське мовознавство досліджує семантичну структуру речення 3 урахуванням семантичного типу предиката й особливостей його лівобічної та правобічної валентності. При цьому актантну (що включає актанти - синтаксеми, зумовлені валентністю предиката) рамку трактують як реалізацію валентності предикатної синтаксеми» (Шульжук, 183). Л. Теньєр вперше виділив і обгрунтував термін «валентність» у мовознавстві. Одночасно вчений випрацював основні теоретичні засади синтаксичних залежностей (Теньєр, 183). На нашу думку, синтаксис залежностей, i, зокрема, семантико-синтаксична залежність уможливлює чіткіше осмислення граматичної структури різнотипних речень (Масицька 22-24). Питання про розмежування залежності i валентності $\epsilon$ проблемним. У сучасній граматиці валентність теоретично витлумачена крізь призму функційного аналізу синтаксичних явищ і спрямована на дослідження тих мовних одиниць, що функціонують не ізольовано одна від одної, а перебувають у тісному взаємозв'язку в структурі речення. Валентність аналізують на морфологічному рівні відповідно до різних частин мови. У новітніх мовознавчих студіях валентність інтерпретують як міжрівневу категорію (Костусяк, Структура 185-282; Костусяк, Міжрівневі 16-22). Вважаємо, що у семантико-синтаксичній структурі речення семантико-синтаксична залежність чіткіше акцентує увагу на залежних від предиката субстанційних компонентах.

У семантико-синтаксичній структурі речення виокремлюємо залежні від предиката суб'єктну, об'єктну, адресатну, інструментальну та 
локативну синтаксеми. Суб'єктну синтаксему співвідносять у семантикосинтаксичній структурі речення із поняттям «суб'єкт». І. Вихованець, аналізуючи категорію суб'єкта, зазначає, що з «ним пов'язані терміни «суб'єктне значення», суб'єктна функція», «суб'єктне відношення», «суб'єктна валентність» (Вихованець, «Суб'єкт», 611). Вважаємо, що, досліджуючи семантико-синтаксичну структуру речення, потрібно звернути увагу на поняття 'суб'єктна залежність'. О. Межов виокремив суб’єктну мінімальну семантико-синтаксичну одиницю і встановив іiі специфічні ознаки: «а) суб'єктна семантико-синтаксична функція; б) лівобічна валентна позиція стосовно предиката в елементарному реченні; в) активність (при предикатах дії) / пасивність (при інших предикатах; г) поєднання з усіма валентними класами та семантичними типами предикатів; г) найширша семантична диференціація; д) найбільша кількість морфологічних варіантів; е) типова центральна формальносинтаксична позиція підмета; є) типова комунікативна позиція теми (даного) за актуального членування речення. <...> вона, як і інші субстанційні синтаксеми, залежить від предиката, який зумовлює ії семантичну диференціацію» (Межов, Типологія 125). Аналіз лівобічної залежності, зреалізованої суб'єктом у семантико-синтаксичній структурі речення, сприяє якнайглибшому проникненню в сутність лінгвістичних процесів у реченнєвих конструкціях.

У семантико-синтаксичній організації реченнєвої конструкції предикати зумовлюють суб'єктну залежність трьох основних різновидів:

1) залежність суб'єкта дії, напр.: ...дівчина <...> читала якусь книжку (Струцюк 50); Дядько Іван вже давно виготовляє березові віники... (Струцюк 59); $\boldsymbol{Я}$ доглядав Ігорка (Струцюк 141); ...nовстанці переміщалися у більш безпечні місця (Струцюк 167); ... хтось уночі поцупив наш харч (Струцюк 182);

2) залежність суб'єкта процесу, напр.: ...nрипече небесне світило ... (Струцюк 10); ...nара <... жила дружно (Струцюк 11); ...жживає урочище (Струцюк 16); ...ночують лебеді... (Струцюк 16); ... скриплять старі стовбури сосон... (Струцюк 29); ...жінка ридає (Струцюк 29); ... почали падати і волоські горіхи (Струцюк 67); Тільки сливи <...> цвіли... (Струцюк 83);

3) залежність суб'єкта стану, напр.: Роман згоджується... (Струцюк 7); ...дружина розсердилася (Струцюк 9); Динара ненавидить мужчин (Струцюк 14); ...світлішає озеро... (Струцюк 16); - Джаним я цього не довіряю (Струцюк 18); Роман <... почервонів (Струцюк 18); Красуня з кожною чаркою все густіше червоніла... (Струцюк 20); Я боюся... (Струцюк 22); Максим не любив його [батька] (Струцюк 41); ...сільська фельдшерка цвіте (Струцюк 62); [Максим] ніби злякався (Струцюк 69). У межах залежності суб'єкта стану виокремлюємо: а) залежність суб'єкта всеохопного стану: Почало сутеніти (Струцюк 70); $\mathrm{Ha}$ проводи випогодилося... (Струцюк 115); ...вже зовсім стемніло... (Струцюк 90); 
б) суб'єкта якісного стану, напр.: Жінка, щоправда, видалася трохи гордою i незалежною (Струцюк 5); Фельдшерка, без сумніву, задоволена (Струцюк 62); Ранок видався прохолодним і мовчазним (Струцюк 157); в) суб'єкта кількісного стану: ...вовченят було аж шестеро (Струцюк 123); Сьогодні ж неділя і людей навколо багато (Струцюк 182); г) суб'єкта стану-відношення: Колумб й Хейєрдал були старші од нас (Струцюк 171); Я був од Сергійка на два роки молодший (Струцюк 172).

Семантико-синтаксична залежність суб'єкта дії підпорядкована предикатам дії. Предикатові та залежному від нього суб'єктові належить основна роль в утворенні речення. У системі мови предикатні синтаксичні одиниці $\epsilon$ центральними компонентами речення із семантикою ознаки. У реченнєвих конструкціях дієслова, прикметники, прислівники, числівники виконують фукнкцію предиката. Компоненти з предметним значенням $\epsilon$ непредикатними одиницями. Семантичні ознаки непредикатних компонентів визначають предметність позначуваних ними об'єктів.

Предикат здатний породжувати залежний суб'єктний компонент (суб'єкт дії, суб'єкт процесу, суб'єкт всеохопного стану, суб'єкт стану, суб'єкт якісного стану, суб'єкт кількісного стану, суб'єкт станувідношення). І. Вихованець слушно зауважив: «Семантична диференціація суб'єктної синтаксеми залежить передусім від характеру предиката найголовнішої у семантико-синтаксичній структурі речення синтаксеми» (Вихованець, Нариси 112). Дослідник відзначав, що залежні від предикатів субстанційні синтаксеми виявляють неоднаковість щодо діапазону сполучуваності з класами предикатів і щодо семантичного варіювання (Вихованець, Граматика 248).

Семантико-синтаксичну залежність суб'єкта дії в прозових творах Йосипа Струцюка визначають предикати дії, виражені переважно такими основними лексичними групами:

1) предикати, що позначають активну діяльність суб'єкта дії: ...[Лукія] наварила, напекла з чого мала (Струцюк 115); - Але ж ти тією гімнастикою накачав собі м'язи... (Струцюк 47); А в лісі спочатку [Іван] підстрелив тетерука... (Струцюк 103); ...[хлопці] будують свинарник у сусідньому селі (Струцюк 152);

2) предикати, що позначають більший або менший ступінь інтенсивності дії, спрямованої на об’єкт, напр.: [Михайло Іванович] Підсмажив йому на вогні гуску... (Струцюк 17); У викопану яму чоловік вбиває кілок... (Струцюк 120); А пса ще при Іванові сіроманець задавив (Струцюк 123); ...[Демиденко] почистив зуби, під краном до пояса сполоснувся холодною водою (Струцюк 137);

3) предикати, що виражають дію суб'єкта на об'єкт: [Лукія] Найперше висіває холодостійкі моркву, петрушку, пастернак, редьку, цибулю, горох (Струцюк 120); Сергійко <...> відрізав кусень шириною в долоню (Струцюк 170); 
4) предикати дії із семантикою «писання», напр.: ...nисав один провінційний віршомаз... (Струцюк 10); Після того він [Роман] <... почав писати... (Струцюк 16);

5) предикати на позначення мовленнєвої діяльності, напр.: ...малий Соломон <...> виголошував афоризми... (Струцюк 44); А люди так і нічого не сказали (Струцюк 104); А на Волині старий Кухта усе когось випитував... (Струцюк 155); ...дідусь <... розповідає... (Струцюк 157); Ha цьому не раз наголошувала вчителька Марія Іванівна (Струцюк 168);

6) предикати на позначення виду діяльності, напр.: - Давай-но я повеслую ... (Струцюк 173); ...я веслував вправніше... (Струцюк 173);

7) предикати, які у своїй семантичній структурі мають лексичне значення «передавання об'єкта», напр.: - Передай їи вітання (Струцюк 47); ...даси [мені] десять тисяч баксів... (Струцюк 135); - А оце в торбинці білочка передала для чубариків-чубчиків горішки (Струцюк 108);

8) предикати зі значенням руху: [Лукія] Подалася до лісу (Струцюк 121); ...до села підходять звірі (Струцюк 123); ... хлопчик бігає по кімнаті (Струцюк 140); Він [Максим] рушив до місця... (Струцюк 44); ...nрийшов Федул... (Струцюк 119); А він [Роман] пішов за Удаль-річку в сусіднє село (Струцюк 151); Вони довго ходили цим запущеним цвинтарем... (Струцюк 154);

9) предикати, що позначають переміщення суб’єкта дії в просторі, напр.: А люди <... їдуть $і$ їдуть на заробітки (Струцюк 149); На вокзал [Максим] приїхав рівно в 15.40 (Струцюк 43); ...син на сей раз не приїхав (Струцюк 105); ...nриїде Славко... (Струцюк 119); ...[Роман] поӥхав би за Буг (Струцюк 150); Плавали ж колись козаки по Дніпру аж до Чорного моря (Струцюк 167); Пливли ми за течією... (Струцюк 181);

10) предикати, що позначають переміщення в просторі суб’єкта дії та об'єкта із семантикою «нести»: ... лисиця останніх курей з курника винесла (Струцюк 123); ...[Іван] все це виніс на сани (Струцюк 104); ... а той [Петрик Покотило] відніс його [лебедя] до озера... (Струцюк 159); ...він [дідусь] приніс нам дров... (Струцюк 177);

11) предикати із семантикою «везти», що позначають переміщення в просторі суб'єкта дії та об'єкта, напр.: ...плівку <...> привіз Микола з Києва... (Струцюк 120); Він [Михайло Іванович] їх [риболовецьке причандалля] <...> з собою привіз (Струцюк 11); Люся в магазин аж три мішки привезла (Струцюк 103); ...хвороби не привіз би додому (Струцюк 152); ...він [дідусь] його [лід] <...> вивіз човном на берег... (Струцюк 162); Зазвичай він [Максим] возив свої картини на базар... (Струцюк 63).

Семантичне вираження суб'єкта дії, залежного від предикатів дії, уможливило виокремити 24 групи, у яких суб'єкт дії репрезентує:

1) ім'я особи, напр.: ...Роман <...> почав приглядатися до своїх сусідів (Струцюк 5); ...Михайло Іванович <... працював першим секретарем райкому комсомолу... (Струцюк 8); ...Віктор Станіславович не приїхав 
(Струцюк 11); Зі спальні вийшов Микола (Струцюк 107); Лукія заправила березовий сік висушеними яблуками ... (Струцюк 115);

2) прізвище особи, напр.: ...Лук'яненки, Сороки, Чорноволи, Шумуки <...> освоювали вічну мерзлоту... (Струцюк 7); I Щербицький піднявся на трибуну... (Струцюк 111);

3) загальну назву особи, напр.: ...nampiomu <..> самі їхали в глухі села... (Струцюк 7); ...чоловік, повірте, в географії орієнтується... (Струцюк 10); Жінка вперше ледь помітно усміхнулася (Струцюк 12); ...хлопець зробив фіззарядку... (Струцюк 15); ...мужики <...> грали в карти... (Струцюк 34); А невзабарі гість пішов (Струцюк 111);

4) номінацію членів сім'ї, напр.: ...дід потонув в Одері (Струцюк 41); Казала мати... (Струцюк 41); Син навіть у паспорті хотів ідентифікуватися «по матері» (Струцюк 41); Невістка <...> руками сплеснула (Струцюк 107); Внуки Артем і Павлик наввипередки кинулися до бабусі... (Струцюк 107); I брати <..> подалися із цвинтаря на шлях (Струцюк 118);

5) назву виробничої діяльності особи, напр.: ...рибалка <...> витягнув таки із ями двопудового сома... (Струцюк 31); ...gельдшерка <..> попросила... (Струцюк 33); ...намагався заспокоїти його знайомий скрипаль (Струцюк 63); ...пічник <...> приніс навіть свіжу рибу... (Струцюк 157); ...комірник <...> на вагу кинув [щуку] (Струцюк 166);

6) назву посади, напр.: Голова міської ради набрав телефон... (Струцюк 131); ...nрезидент ключі від квартир вручав військовослужбовцям... (Струцюк 149);

7) номінацію соціального стану, напр.: ...nартійні боси <... запливали аж на середину Прип'яті... (Струцюк 100); ...nенсіонер у самостійній Україні отримує [гроші] (Струцюк 150); - А де пан працює? (Струцюк 152)

8) номінацію, що належить до сакральної лексики, напр.: ...богиня <...> вийшла із води... (Струцюк 9); ...монах <...> ікони малював... (Струцюк 166); ...Творещь його [світ] створив для радости й добра (Струцюк 167); Таких Ісус із храму виганяв, здається в Ерусалимі (Струцюк 61);

9) історизми, напр.: ...княжі дружинники сповідалися... (Струцюк 151); ...гетьман Богдан молився... (Струцюк 171) ;

10) національність, напр.: - Мене німець на фронті не поцілив... (Струцюк 100); Мойй нозі такий барометр <...> подарував німець... (Струцюк 153);

11) топоніми, напр.: ...Чорногузка омиває береги... (Струцюк 166); ...Прип'ять витікає не там... (Струцюк 171);

12) назви тварин, напр.: Кицька, певне, із півбляшанки з'їла... (Струцюк 39); ... на соснах стрибали вивірки... (Струцюк 101); Поряд, на поляні, залишила на снігу свою каліграфію ворона (с. 101); ...підійшов лось... (Струцюк 101); ...кінь шарпнув сани... (Струцюк 101); ...ондатра <..> попливла до протилежного берега (Струцюк 175); 
13) назви птахів, напр.: ...в розмову встряють тетеруки, дрозди, горлиці, дятли, канюки! (Струцюк 16); Ось підлетіла синичка... (Струцюк 16); Зозулі <...> накують тут більше літ... (Струцюк 16); ... пройдеться берегом сіра чапля... (Струцюк 16); Десь над головою розкидав срібне намисто жайворонок... (Струцюк 175); ...Лебеді прилетіли! (Струцюк 156);

14) назви комах, напр.: У Лукії мурашки побігли по спині (Струцюк 107); ... іноді нас супроводжували метелики... (Струцюк 181); ... на березі перед нами <...> стрибали <...> коники (Струцюк 181);

15) назви риб, напр.: ...[сом] на глибині ходить (Струцюк 17);

16) назви рослин, напр.: танцювала риба з раком, а петрушка 3 пастернаком (Струцюк 170);

17) назви дерев, напр.: Берези першими в лісі на свої оголені плечі відкинули зелені коси (Струцюк 114);

18) предметне значення, напр.: ...вода <...> струмочками стікала по ї̈ <... стегнах (Струцюк 12); ... ударили важкі краплі дощу... (Струцюк 28); Бо дозиметри <...> не фіксували справжніх показників (Струцюк 111);

19) абстрактну номінацію, напр.: ...ніч <...> розмовляла сама з собою... (Струцюк 15); ...у середину озера навідліг угатив грім... (Струцюк 27); ...вітер уже розхитував старе верховіття сосон... (Струцюк 28); Тільки та мелодія підсунулась ближче до горла... (Струцюк 41); ...наближається негода (Струцюк 65);

20) назви пори року, напр.: Весна завжди підкидає заняття людям (Струцюк 119);

21) номінації астрономії, напр.: ...місяць сам себе лоскотав під пахвами ... (Струцюк 15); ... світило появиться над озером... (Струцюк 15);

22) іншомовні лексеми, напр.: $A$ кючюк ханим уміє плавати? (Струцюк 22);

23) анатомічні назви, напр.: ...cерце перестало битися (Струцюк 28);

24) імпліцитне вираження суб'єкта дії, напр.: - Тільки <... витягни шию назустріч адміністрації президента (Струцюк 6); ...Чорновола обкидав брудом з ніг до голови (Струцюк 7); - Йди в школу (Струцюк 7); ...батьків ї̈ депортували в Середню Азію (Струцюк 14); Ще пообрізував зайві гілляки на деяких деревах... (Струцюк 42); ...обійшов довкола будівлю $i$ позаглядав у вікна... (Струцюк 101).

Поширення суб’єктної синтаксеми у функції залежності суб’єкта дії на назви неістот спричинене явищами метафори (персоніфікації). У прозі Йосипа Струцюка предмети, явища природи, виражені залежним від предиката суб'єктом дії, деколи набувають властивостей людини: ...nотяг <...> заколисав його... (Струцюк 43); ...і дні побігли швидше (Струцюк 114); Останній рясний дощ намив їй [Лукії] трохи мулу за хвіртку з дороги (Струцюк 23); ...барабанні перетинки лупџюють знайомі ще з дитинства мелодії й слова (Струцюк 126); Прип'ять несла свою холодну каламутну $і$ хвору воду... (Струцюк 122). Поширення суб'єктної синтаксеми у функції 
залежності суб'єкта дії на назви неістот спричинене явищами метафори (персоніфікації).

Залежний суб'єкт дії представлений переважно іменниками, напр.: ...у нас торгаші храми будують (Струцюк 61); Після такої роботи Іван зазвичай спльовував у долоні... (Струцюк 121); Перед очима якісь невиразні картини почали вимальовуватися... (Струцюк 121), займенниковими слова (див. гетерогенну класифікацію частин мови: центр частин мови формують іменники і дієслова як суто автономні знаки, а периферію прикметники, прислівники та числівники як менш автономні знаки (Вихованець, і Городенська 26-29), напр.: ...xто <..> воював <...> за незалежність батьківщини...? (Струцюк 6); ...я <...> читав лекції з новітньої історії... (Струцюк 8); Всі дружно підгодовували перелітних птахів (Струцюк 160) у називному відмінку. Значно рідше автор послуговується субстантивованим прикметником, напр.: До нас підійшла така вже старенька, що на її горбі можна було райдугу вигинати (Струцюк 183); [Романові] відповіла миловидна (Струцюк 152).

Для формально-синтаксичної структури речень у прозі Йосипа Струцюка характерний простий підмет: Іван підняв догори батога... (Струцюк 101); Міліціонер кивнув головою (Струцюк 105); Мати відразуж забрала в нього торбинку (Струцюк 108), рідше - складений підмет: I мu 3 Сергійком якось на ямі також підчепили [щуку] (Струцюк 166); I брати разом із Сюсею <... підійшли ... (Струцюк 116); ...вони із Павлом почали обережніше наганяти на партійні засади звірів (Струцюк 100); ...Артемчик з Павликом прийшли... (Струцюк 109). В оповіданнях Йосипа Струцюка спостерігаємо також функціонування однорідних підметів: ...бабусі й дідусі поспішали до озера (Струцюк 156); Хлопці й дівчатка поопускали голови (Струцюк 163).

У системі сучасної української мови визначене відповідне місце для суб'єктного субстанційного компонента. Він стоїть переважно перед предикатом i тому репрезентує лівобічну семантико-синтаксичну залежність суб'єкта дії. Цей усталений мовною системою порядок розташування лівобічних i правобічних компонентів, зумовлених семантикою предикатів дії, у текстах художніх творів зазнає різних модифікацій, що спостерігаємо в прозі Йосипа Струцюка, Лівобічний залежний суб’єкт дії займає як препозицію: ...бабця Надька в ній хліб $i$ пироги пекла... (Струцюк 66); мати завше це робила... (Струцюк 67); Сусідка Марія подарувала віночок цибулі, кілька головок часнику (Струцюк 68); Тільки Перепелюк і після того нічого не сказав (Струцюк 91), так і постпозицію щодо предиката: Вже давно підім'яли небо крилами жсуравлі (Струцюк 65); ... пасуться корови... (Струцюк 64); ... гагакнув грім (Струцюк 29); А наступного дня вже вибухнув четвертий реактор (Струцюк 100); ...дзвонила Віталіна (Струцюк 59); ...на соснах стрибали вивірки... (Струцюк 101). 
У реченнях на кшталт: Сани ковзнули давньою березовою просікою $i$ вискочили на дорогу... (Струцюк 101); Раніше автобуси курсували через Хворостів до Чорнобиля... (Струцюк 105); Якось на повній швидкості промчався БТР... (Струцюк 104); ...на шлях вискочило авто (Струцюк 105); ...човен поламав-потрощив носом перед собою лід (Струцюк 162); ...човен пішов швидше плесом... (Струцюк 173) репрезентовано семантико-синтаксичну залежність інструментального суб'єкта, яку в прозі Йосипа Струцюка зумовлюють переважно предикати дії зі значенням руху.

Висновки та перспективи досліджень. Структурна організація простого речення та його компонентів сформована предикатом і його здатністю зумовлювати семантико-синтаксичну залежність. Предикати дії вмотивовують семантико-синтаксичну залежність суб'єкта дії. Їхнє функційне оточення - субстантивні компоненти, що перебувають у семантико-синтаксичній залежності від конкретного предиката. Семантичний потенціал предикатів дії визначає кількість предметних компонентів і впливає на їхню значеннєву диференціацію. Семантикосинтаксична залежність суб’єкта дії підпорядкована предикатам дії. Її аналіз репрезентує основні тенденції організації семантико-синтаксичної структури речення. У прозі Йосипа Струцюка залежний суб'єкт дії репрезентований різними семантичними групами. Перспективним вважаємо поглиблене дослідження семантичного ускладнення субстанційних семантико-синтаксичних залежностей у мовотворчості волинського письменника.

\section{Список використаної літератури}

Андерш, Йосип. «Типологія простого слов'янського речення і український мовний матеріал». Ucrainica I. Současná ukrajinistika: Problémy jazyka, literatury a kultury. K 65 narozeninám prof. Josefa Anderše. Sborník článkủ. 2. Olomoucké sympozium ukrajinistů, 26-28 srpna 2004. Olomouc: Univerzita Palackého v Olomouci, 2004, s. 21-5.

Вихованець, Іван. Нариси з функціонального синтаксису української мови. Київ: Наукова думка, 1992.

Вихованець, Іван. Граматика української мови. Синтаксис. Київ: Либідь, 1993.

Вихованець, Іван. «Суб’єкт». Українська мова: енциклопедія, за ред. В. М. Русанівського, і 0. О. Тараненка. Київ, 2000, с. 611-2.

Вихованець, Іван, і Городенська, Катерина. Теоретична морфологія української мови. Київ: «Пульсари», 2004.

Городенська, Катерина. Деривація синтаксичних одиниць. Київ: Наукова думка, 1991.

Загнітко, Анатолій. Теоретична граматика української мови. Морфологія. Синтаксис. Донецьк, 2011.

Костусяк, Наталія. Структура міжрівневих категорій сучасної української мови. Луцьк: Волинський національний університет ім. Лесі Українки, 2012.

Костусяк, Наталія. Міжрівневі категорії сучасної української літературної мови. Автореф. дис. ...д-ра філол. наук: 10.02.01. Київ, 2013.

Масицька, Тетяна. Типологія семантико-синтаксичних залежностей. Луцьк: Твердиня, 2016. 
Межов, Олександр. Суб'єктні синтаксеми у структурі простого речення. Луцьк: РВВ Вежа Волинського державного університету ім. Лесі Українки, 2007.

Межов, Олександр. Типологія мінімальних семантико-синтаксичних одиниць. Луцьк: Волинський національний університет ім. Лесі Українки, 2012.

Плющ, Марія. Словоформа у семантично елементарному та ускладненому реченні. Київ: Видавництво Національного педагогічного університету імені М. П. Драгоманова, 2011.

Струцюк, Йосип. Усе не так просто. Луцьк: «Терен», 2010.

Теньер, Люсьен. Основы структурного синтаксиса. Москва: Прогресс, 1988.

Филлмор, Чарльз. «Дело о падеже». Новое в зарубежной лингвистике. вып. 10, 1981, c. $369-495$.

Чейф, Уоллес. Значение и структура языка. Москва: Прогресс, 1975.

Шульжук, Каленик. Синтаксис украӥнської мови. Київ: Видавничий центр «Академія», 2004.

\section{References}

Andersh, Yosyp. “Typolohiia prostoho slovianskoho rechennia i ukrainskyi movnyi material”. Ucrainica I. Současná ukrajinistika: Problémy jazyka, literatury a kultury. K 65. narozeninám prof. Josefa Anderše. Sborník článků. 2. Olomoucké sympozium ukrajinistů 26 - 28 srpna 2004. Olomouc : Univerzita Palackého v Olomouci, 2004, s. 21-5.

Vykhovanets, Ivan. Narysy z funktsionalnoho syntaksysu ukrainskoi movy. Kyiv: Naukova dumka, 1992.

Vykhovanets, Ivan. Hramatyka ukrainskoi movy. Syntaksys. Kyiv: Lybid, 1993.

Vykhovanets, Ivan. "Subiekt". Ukrainska mova: entsyklopediia, edited by V. M. Rusanivskyi, and 0. O. Taranenko. Kyiv, 2000, pp. 611-2.

Vykhovanets, Ivan, and Horodenska, Kateryna. Teoretychna morfolohiia ukrainskoi movy. Kyiv: Pulsary, 2004.

Horodenska, Kateryna. Deryvatsiia syntaksychnykh odynyts. Kyiv: Naukova dumka, 1991.

Zahnitko, Anatolii. Teoretychna hramatyka ukrainskoi movy. Morfolohiia. Syntaksys. Donetsk, 2011.

Kostusiak, Nataliia. Struktura mizhrivnevykh katehorii suchasnoi ukrainskoi movy. Lutsk: Volynskyi natsionalnyi universytet im. Lesi Ukrainky, 2012.

Kostusiak, Nataliia. Interlevel category of the modern Ukrainian language. PhD Thesis Abstract. Kyiv, 2013.

Masytska, Tetiana. Typolohiia semantyko-syntaksychnykh zalezhnostei. Lutsk: Tverdynia, 2016.

Mezhov, Oleksandr. Subiektni syntaksemy u strukturi prostoho rechennia. Lutsk: RVV Vezha Volynskoho derzhavnoho universytetu im. Lesi Ukrainky, 2007.

Mezhov, Oleksandr. Typolohiia minimalnykh semantyko-syntaksychnykh odynyts. Lutsk: Volynskyi natsionalnyi universytet im. Lesi Ukrainky, 2012.

Pliushch, Mariia. Slovoforma u semantychno elementarnomu ta uskladnenomu rechenni. Kyiv: Vydavnytstvo Natsionalnoho pedahohichnoho universytetu im. M. P. Drahomanova, 2011.

Strutsiuk, Yosyp. Use ne tak prosto. Lutsk: Teren, 2010.

Tener, Liusen. Osnovy strukturnoho syntaksysa. Moskva: Prohress, 1988.

Fyllmor, Charlz. "The Case for Case". Novoe v zarubezhnoi lynhvystyke, iss. 10, 1981, pp. 369495.

Chafe, Wallace. Meaning and the structure of language. Moskva: Prohress, 1975.

Shulzhuk, Kalenyk. Syntaksys ukrainskoi movy. Kyiv: Vydavnychyi tsentr "Akademiia", 2004. 